看護研究報告：

\title{
NICU における出生前妊婦訪問の現状と課題
}

\author{
中 沢京子*
}

ハイリスク妊婦や家族に対して NICU 看護師が出生前妊婦訪問 (以下妊婦訪問と略す) を行うことは, 妊婦を取り巻く家族の不安の軽減や出生後の家族支援について有効であ る。さらに家族の視点に立った妊婦訪問を行っていくために, 訪問内容を分析し現状と課 題について検討する。

妊婦訪問を実施した62家族に対して，妊婦訪問依頼内容と結果報告書から妊婦背景・対 象・妊婦訪問に期待することについて調査した。

NICU 入院となった家族の中で，産科病棟で妊婦訪問を受けたのは19 1\%であった。対 象者の妊娠週数は35週未満が81％であった。NICU 入院となる可能性が高い家族の心理的 不安ははかりしれない。妊婦訪問時, 本人および家族が対象となっていたのは71\%であっ た。情報として期待している内容は, 児の発達・発育に伴う障害や予後に関すること， NICU での入院環境から経済面に関すること，出産にいたる産科的経過であった。このこ とから妊婦訪問を行うときは, 夫婦・家族を対象とすることで家族の状況を受け入れ児へ の思いを共有していくことは, 家族関係を構築していくための支援につながる。妊婦訪問 を行う看護師は, NICU の専門性と周産期全般の知識を合わせ持った指導ができる人材が 求められる。

(1)NICU (2)出生前妊婦訪問 (3)産科との連携 (4)家族支援

$$
\text { ।.はじめに }
$$

周産期医学の発達に伴い, 早産児や低出生体 重児の治療効果に伴う生存率は上がっており， NICU への期待は高まっている。しかし , ハイ リスク妊婦や炎の家族にとっては1日でも長く 妊娠を継続させたいという希望は変わらない。 そこで, NICU 看護師の役割として産科病棟入 院中から家族支援として出生前妊婦訪問 (以下 妊婦訪問と略す)に取り組んでいる。産科病棟 との連携を図りながら，NICU入院が予測でき る家族に対して，効果的妊婦訪問を行うため に, 訪問内容を分析して今後の課題を検討した

* $=$ 300-0053 茨城県土浦市真鍋新町11-7 土浦協同病院周産期センターNICU 師長 (受付 : 2004年 3 月 2 日)
ので報告する。

$$
\text { II. 研 究方 法 }
$$

概要) 当院の病床数1,034床昭和53年茨城県 初の未熟児センターを設置。平成 5 年周産期セ ンター設立, NICU 9 床, 未熟児センター25床

対象) ハイリスク妊婦として産科病棟入院中 で妊婦訪問を希望し実施した62家族

方法) 産科病棟より妊婦訪問依頼書 (表 1 ) と訪問後の結果報告書（表 2 ) による指導内容 から妊婦の背景 ·対象 ·妊婦訪問に期待するこ とを分析し今後の妊婦訪問の課題を検討する。

妊婦訪問係り (師長・主任・主幹・リーダー ナース 2 名) は 1 名で行い。訪問時間は30〜40 分とした。 
表 1 . 妊婦訪問依頼用紙

\begin{tabular}{|ll|}
\hline 氏名 & 年齢 \\
既往歴 & 家族構成 \\
妊娠週数 & 診断名 \\
単胎・双胎・品胎 & \\
妊娠経過 & \\
母親の心理的状態 & \\
家族の受け入れ状況 & \\
訪問希望日 & \\
\hline
\end{tabular}

表 2 . 結果報告書

\begin{tabular}{|l|}
\hline 氏名 \\
訪問時情報 \\
本人・訪問月日 \\
サポート内容 \\
サ配していること \\
同席者の有無 \\
訪問担当者 \\
\hline
\end{tabular}

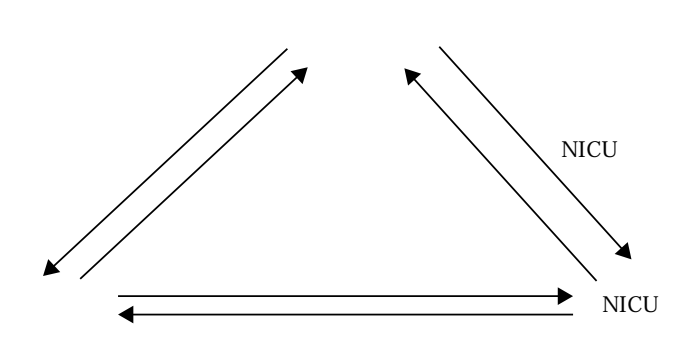

図 1 . 妊婦訪問ルート

III . 結

果

現在行われている妊婦訪問ルートは, 入院中 のハイリスク妊婦に対して産科スタッフより妊 婦訪問についての説明を行い希望のあつた家族 に対して妊婦訪問依頼書にて NICU八依頼す る。

弚の後 NICU 妊婦訪問係りが，ハイリスク 妊婦の元へ訪問に伺う。訪問後妊婦訪問結果報 告書を産科病棟にフィードバックする，翌日不 安増強の確認を行うため再度訪問し連携を図る (図 1 )。

\section{NICUにおける入院状況}

2 年間における NICU 入院患者内訳とし て，体重別入院状況は1，000g 未満11\%, 1,500g 未満16\%，1 ,500g 以上73\%だった。入院方法

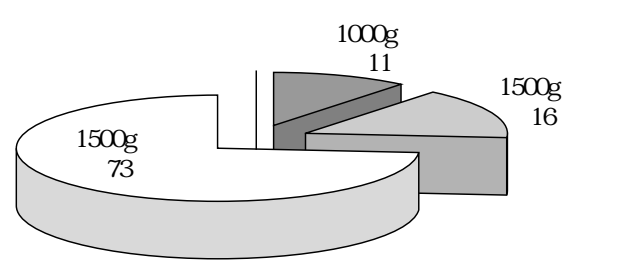

体重別入院状況

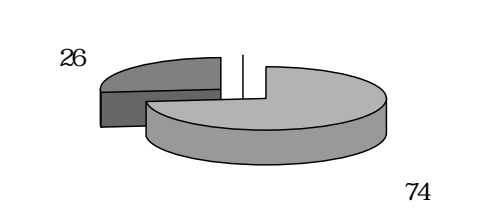

図 2.2 年間の入院患者内訳 $(n=439)$

\section{訪問をした妊婦年齢}
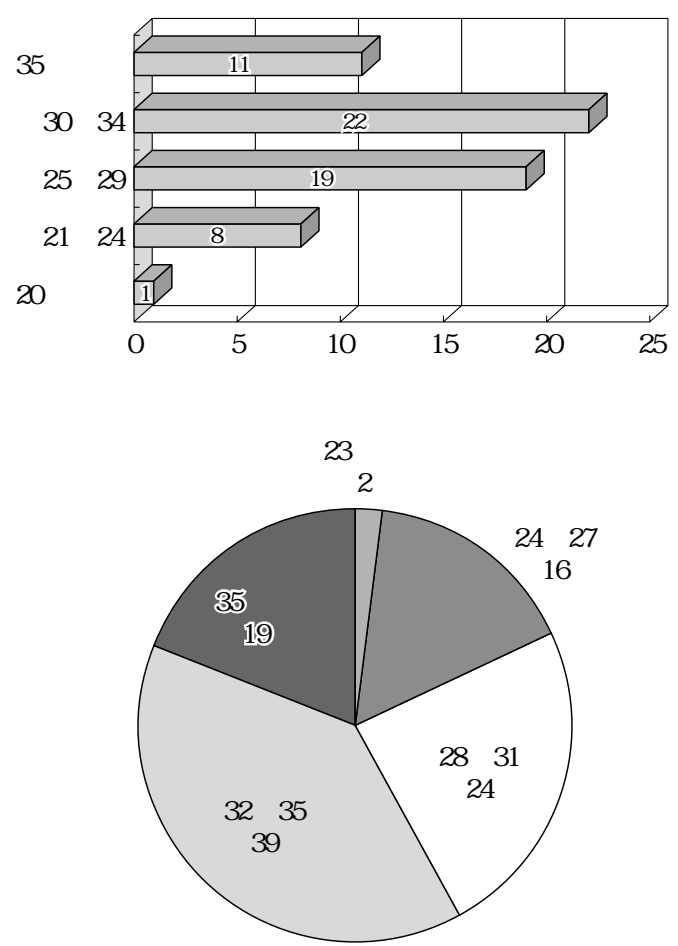

図 3 . 訪問時の妊婦背景

については, ハイリスク娃婦として院内管理さ れて出生した児74\%，新生児搬送での入院は $26 \%$ だった(図 2 )。 


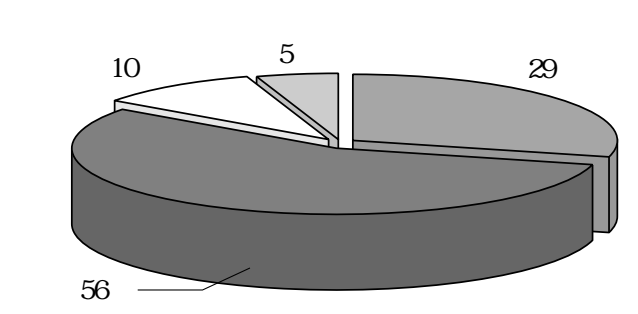

図 4 .訪問時の同席者

\section{2 . 妊婦の背景}

年齢は，30〜34歳が22人 (35 5\%) と多く， ハイリスクとされる若年・高齢妊婦は13人 (20 1\%) だった。妊婦訪問を受けたときの妊 娠週数は23週以前 $2 \% ， 24 〜 27$ 週16\%，28～31 週23\%，32～35週40\%，36週以降は19\%だった

(図 3 )。

\section{3. 妊婦訪問の対象者}

妊婦訪問は個別訪問を基本として行い，場所 は個室または病室を妊婦が選択する。訪問担当 者はNICU スタッフ1名。対象者は妊婦のみ $29 \%$ ，夫婦56\%，妊婦と夫以外の家族10\%，夫 婦と家族 $5 \%$ だった (図 4 )。

\section{4 . 妊婦訪問時の説明内容}

訪問者の自己紹介を行い, 現在心配している こと, 知りたいことなど妊婦および家族より吐 露する場を作り, 共通認識を持てるようにす る。アルバム (NICU 内の環境独自にスクラッ プしたもの) を活用して NICU 内の説明をし た。入院から退院までの経過と起こりうる身体 上の問題，妊婦を支える夫の役割と家族の支 援, NICU 見学を通して環境への適応を促した (表 3 )。

$$
\text { IV. 考察 }
$$

周産期医療の進歩により，ハイリスク妊婦と 長期に集中治療が求められる览が増加してい る。従来の医療は児の救命だけを重視していた が, 光れらを取り巻く母親・父親など家族を中 心としてケアしていくことがさらに求められ る。光こで, 家族関係を構築していくための両 親への支援は産科病棟入院中から開始される必 要がある。ハイリスクの妊婦の家族は, 予期せ
表 3 . 妊婦訪問で知りたい情報 $(n=62)$

複数意見

\begin{tabular}{|c|c|c|}
\hline 皆 & $\begin{array}{l}\text { 児の発達・発育・後遺症・治療について } \\
\text { 入院期間・退院の目安について } \\
\text { 胎児の発育不良の原因について }\end{array}$ & $\begin{array}{l}44 \\
22 \\
11\end{array}$ \\
\hline $\begin{array}{l}\text { 母 } \\
\text { 情 } \\
\text { 報 }\end{array}$ & $\begin{array}{l}\text { 母乳分泌・母乳栄養について } \\
\text { 出産方法 (帝王切開・分婏) について } \\
\text { ハイリスクの妊婦ストレスと入院生活について } \\
\text { 術後経過・入院期間 }\end{array}$ & $\begin{array}{r}13 \\
12 \\
6 \\
2\end{array}$ \\
\hline $\begin{array}{l}\text { 光 } \\
\text { 他 }\end{array}$ & $\begin{array}{l}\text { NICU の環境について } \\
\text { 面会の方法について } \\
\text { 児の入院費用について }\end{array}$ & $\begin{array}{r}13 \\
8 \\
3\end{array}$ \\
\hline
\end{tabular}

ぬ産科病棟への入院や予期せぬ出産によって， 生まれてくる児を家族の一員として迎える精神 的準備が整っていないままに出産を迎えようと 心理的危機状況にあります。

産科病棟との連携として, 妊婦訪問依頼書に は胎児情報だけでなく母親の精神状態や児に対 する家族の受け入れ，家族構成などの内容が必 要となってくる。日々のハイリスク妊婦一覧表 による状況報告，週 1 回の産科合同による周産 期カンファレンスにより連携を深めていること は対応の柔軟性につながっている。

妊婦訪問を行った妊婦背景については, 若 年・高齢のハイリスク妊婦が高率であったこと は周産期センターとしての特徵といえる。妊娠 週数別では, 低出生体重児の出生が明らかに予 測できることから身体発達・発育・障害につい ての漠然とした不安が妊娠継続とともに常に心 理的にも増強してくる。光こで，妊婦訪問を夫 婦・家族を対象に行うことで，お互いの家族の 思いを話せる場とすることで, 漠然とした不安 が正しい情報を得ることで家族の共有認識を深 め, 家族が妊婦をフォローすることで妊婦の心 理的負担の軽減に効果があるといえる。

訪問において家族が期待する内容について は, NICU の専門性以外にも社会的支援や周産 期全般の幅広い内容が求められていた。

妊婦訪問における予期的指導は, 妊婦・家族 が現状を受容し始めたころ，漠然とした不安を 軽減するのに効果的である。また，NICU 見学 を通して児を取り巻く環境をイメージすること 
で家族関係の構築につながる。妊婦訪問後 , 翌 日, 再度訪室しコミュニケーションを図ること は, 信頼関係をより深め, NICUを身近に感じ ていただくことで安心感がさらに高まるといえ る。

$$
\text { V. 結 論 }
$$

NICU における妊婦訪問は, 夫婦・家族を対 象とすることで児への問題を早期から共有して いくことは家族関係の構築に効果がある。ま た，予期的指導を担当するスタッフは, NICU の専門性と周産期全般の知識を合わせ持った指 導ができるように人材育成しておく必要があ る。訪問方法について個別訪問以外にも，ハイ
リスク妊婦・家族を対象とした集団指導として 医師・助産師・NICU スタッフによるチームで の予期的指導を行うことも周産期センターとし て求められている。

$$
\text { 参 考 文 献 }
$$

1 ) 佐藤喜根子, 堺武雄, 横尾京子。低出生体重時 に管理。看護 $2003 ; 55(4)$.

2 ) 入江暁子 . NICUに児が入院した両親への支援 . 周産期医学 $2002 ; 32$.

3) 野馬利恵子, 中林正雄 . 母胎搬送後の長期入院娃 婦の看護 . 周産期医学 $2002 ; 32$ (10).

4 ) 木戶口公一 . 合併症妊婦の心のケア 誰がいつ, 予防的支援ができるのか. 周産期医学 $2002 ; 32$ (1).

5 ) 堀内 勁 . NICUで取り組むファミリーケア .ネ オネイタルケア 2002；(191). 


\title{
Home Visits by NICU Nurses to Pregnant Women \\ — Present State and Problems to Be Solved —
}

\author{
Kyoko NAKAZAWA*
}

Regular visits by an NICU nurse to the high-risk pregnant woman (at ahigh risk of complications) are very effective in allaying the anxiety of her family and supporting the family after childbirth as well. To provide the home-visit services that measure up to the needs of such pregnant women and their families, we analyzed the contents of the services and discuss the present state of affairs and problems yet to be solved.

Using the applications presented by 62 families for the home-visit services and their reports, a survey was conducted to find out the family backgrounds, the recipients of the services other than pregnant mothers, and their expectations from the home-visit program.

Of the families of those pregnant women who were admitted later into the Neonate Intensive Care Unit, $19.1 \%$ had been visited by NICU nurses while the expectant mothers were in the maternity ward. Of those expectant mothers, $81 \%$ were in the 35 weeks or less of gestation. The anxiety of the women who are very likely to be put in the NICU and their family members is great. Pregnant women and their family members who both recieved the home-visit services accounted for $71 \%$ of the 62 families. It was found that they were most anxious to know about the growth and developmental disorders of the unborn babies, prognosis, hospital charges and the process of giving birth. From this, we deemed it highly important for visiting nurses to put themselves in their shoes and share in their feeling toward the neonates. This will surely help them strength the ties that bind the family members together. The nurses are required to have leadership qualities with adequate knowledge of NICU and perinatology.

"NICU Head Nurrse, Perinatal Center, Tsuchiura Kyodo General Hospital, Ibaraki, Japan 